\title{
Findings of a nationwide survey of the diabetes education and training needs of midwives in the UK
}

\author{
UMESH DASHORA, ${ }^{1}$ ALBAN DAVIES HUW, ${ }^{2}$ SHELLEY BENNETT, ${ }^{3}$ ANNE GOODCHILD, ${ }^{4}$ \\ JULIA HUGASON-BRIEM, ${ }^{5}$ GAIL JOHNSON, ${ }^{6}$ ABIGAIL KITT,7 ANNETTE SCHREINER, ${ }^{8}$ DIANE TODD, ${ }^{9}$ \\ JENNIFER YIALLOUROS, 10 ON BEHALF OF THE ASSOCIATION OF BRITISH CLINICAL DIABETOLOGISTS (ABCD)
}

\begin{abstract}
Introduction: The incidence and prevalence of diabetes is increasing in pregnant women. Midwives manage a substantial proportion of care of these women. Currently it is not known whether midwives have sufficient competence in managing these patients well. The Diabetes Care Trust commissioned a survey to assess the diabetes education and training needs of midwives who look after pregnant women with diabetes.

Material and methods: A freedom of information request was made to all the NHS Trusts in the UK to gather relevant information about the roles and responsibilities of midwives in the maternity units in the UK. This was followed by a Survey Monkey questionnaire to midwives in the UK who are members of the Royal College of Midwives to assess their education and training level, needs, desires and views preceded by a test survey on nine midwives.

Results: The survey revealed considerable variation in the roles and responsibilities, current levels of training and education needs of midwives. Over $85 \%$ of midwives expressed a desire to access additional education on diabetes management in different areas. Training in insulin
\end{abstract}

Conquest Hospital, Hastings, UK

Chair of Diabetes Care Trust (ABCD)

A support network for people aged 18-30s with diabetes

PITstop diabetes training

Director of Briem Consulting Ltd

Royal College of Midwives, UK

Senior Quality Improvement Lead (Diabetes) South East Clinical Network, NHS England

Consultant Obstetrician (retired), Darent Valley Hospital, UK

9 Diabetes Specialist Midwife, University Hospitals of Leicester NHS Trust, UK

Director of Qualjenuity

Address for correspondence: Dr Umesh Dashora

Consultant Physician and Lead, Diabetes and Endocrinology, East

Sussex Healthcare NHS Trust, Conquest Hospital, Hastings, East Sussex

TN37 7RD, UK

Telephone: +441424755255

E-mail: u.dashora@nhs.net

http://dx.doi.org/10.15277/bjd.2018.194 initiation and titration, management during labour and ability to contribute to the antenatal clinic was desired by over $85 \%$ of midwives surveyed.

Conclusions: There is an unmet need for structured education and training programmes for midwives in the management of diabetes in pregnancy. We recommend further work in producing tailored and accredited training programmes at different levels to suit the differing needs of midwives and diabetes specialist midwives in the UK.

Br J Diabetes 2018;18:147-153

Key words: Nationwide, diabetes, education, training, midwives

\section{Introduction}

It is estimated that each year up to $5 \%(32,100)$ of women who become pregnant in the UK have either pre-existing diabetes or develop gestational diabetes during their pregnancy. ${ }^{1}$ Of these, $87.5 \%(28,100)$ have gestational diabetes, $7.5 \%(2,400)$ have type 1 and $5.0 \%(1,600)$ have type 2 diabetes. ${ }^{1}$ The prevalence of diabetes and the incidence of gestational diabetes is increasing as a result of higher rates of obesity and more pregnancies in older women. ${ }^{1}$ Diabetes of all types adversely affect the outcome of pregnancy. 2,3

Many recent publications have highlighted suboptimal care, variable achievements and poor outcomes of pregnancy in patients with diabetes in the UK including poor preparation for pregnancy, high rates of ketoacidosis, maternal hypoglycaemia, stillbirths and neonatal hypoglycaemia. ${ }^{4-8}$ Worryingly, the outcomes have largely remained unchanged since previous audits. Excellent national guidelines from the National Institute of Health and Care Excellence (NICE) and Joint British Diabetes Societies for Inpatient care (JBDs-IP) are already available for standardised care and support for pregnant women with diabetes. 1,9 However, their implementation would require widespread uptake, education and training.

Midwives are the key professionals in all pregnancies and are in an ideal position to build trusting relationships with the women they care for. Midwives developing areas of specialist interests and skills have been welcomed by the Royal College of Midwives (RCM). ${ }^{10}$ However, they are not always able to access 
training on important aspects of diabetes care in pregnancy. ${ }^{1}$

NICE Guidance 28 highlights the education criteria for insulin initiation, ${ }^{11}$ and the NICE Quality Standards document focuses on the importance of multidisciplinary support to inpatients with diabetes. ${ }^{12}$ Training and education required for midwives, however, remains unknown.

The Diabetes Care Trust (DCT) is a charity that promotes education for professionals of all disciplines who care for people with diabetes. Together with the RCM, the DCT believes that there may be a need for the development of a training programme for midwives. To understand this in more detail the DCT trustees commissioned a report on the education needs for midwives in caring for their patients with diabetes. The current article summarises the findings of this survey. A full report is available on ABCD Care website. ${ }^{13}$

\section{Methodology}

A working group was established to support the DCT in examining the need for a 'diabetes-in-pregnancy' education programme for midwives by undertaking an education needs analysis (see Appendix 1 at www.bjd-abcd.com). The working group advised on the questions for the Freedom of Information (FOI) request and the survey, promoted the uptake of the survey in their local areas and supported the analysis and interpretation of the responses.

\section{Freedom of information (FOI) requests}

As a precursor to the midwife survey, a FOI request was drafted and issued by email or via Trust websites to all 130 NHS Trusts in England with a midwifery unit between 15 May 2017 and 23 June 2017 (see Appendix 2 at www.bjd-abcd.com). The responses received from 110 of the NHS Trusts were helpful in informing the design of the survey and in targeting the survey.

\section{Midwife survey}

\section{Survey design and testing}

The survey was aimed at practising midwives (see Appendix 3 at www.bjd-abcd.com). It was designed in seven sections and comprised 33 questions covering the details of themselves and their role, expertise, training needs and views. The survey questions were initially based on a previous study undertaken with mental health nurses investigating their diabetes training needs. ${ }^{14}$ The questions were further developed by the working group and by looking at the responses to the FOl request. The final questionnaire wording was agreed after testing the questions on nine midwives in three different NHS Trusts including three diabetes specialist midwives (DSMs), to ensure that the questions were clear, unambiguous and that the content was appropriate. The survey was uploaded to Survey Monkey and a link was sent out by the RCM to all 30,000 active members on their register and to all DSMs identified (83) through the FOI request. The survey was issued between 31 July 2017 and 4 August 2017 and reminders were sent out on 11 September 2017. Seven weeks were allowed for completion, with the survey closing on 25 September 2017.

\section{Findings}

\section{Midwife survey responses}

Following data validation, there were 698 completed responses to the survey (including 76 DSMs) which were eligible for inclusion. Only one question was mandatory and the respondents did not always complete every question.

\section{Information about the midwives surveyed}

- Although a self-selected group, responses came from a good cross-section of midwives, bands, length of service as a midwife, midwife role in diabetes care, working area and additional responsibilities. $90 \%$ of respondents worked in England, 5\% in Scotland and the remaining 5\% in Wales and Northern Ireland.

- Responses were received from bands 5, 6, 7 and 8 with $66 \%$ of responses coming from band 6 midwives. Half of the midwives (49\%) had been qualified for over 15 years. There was a similar number of midwives who had previously trained as a nurse prior to becoming a midwife and those who had entered midwifery without nurse training.

- Eighty (11\%) were DSMs, diabetes link midwives, midwives with special interest in diabetes or similar (DSM), a further $11 \%$ wanted to become a DSM and over half ( $55 \%$ ) wanted to know more about diabetes.

- Nearly half of the midwives (44\%) worked in more than one area of maternity services, with $18 \%$ working across three or more areas. Just over a third of the midwives (36\%) worked in the labour ward and birth centre. Midwives who were DSMs were proportionally less likely to be working in the community than other midwives.

- Between $8 \%$ and $12 \%$ of midwives had additional responsibilities in audit, staff management, safety, quality improvement and risk. Three per cent had additional responsibility for finance/budget management, $21 \%$ for teaching/training and $18 \%$ had no additional responsibilities. Midwives were more likely to have additional responsibilities with higher grading and increased length of service as a midwife. DSMs had proportionally more responsibility in audit and quality improvement and a slightly increased focus on safety and teaching/education than the other midwives who were not DSMs.

\section{Midwives' role in managing diabetes in pregnancy}

- Two-thirds of the midwives provide both high-risk and lowrisk care. DSMs and those wanting to be DSMs are more likely to be providing high-risk and low-risk care. Those who do not want to be DSMs are more likely to be providing lowrisk care or no care to women with diabetes. The definition of high and low risk was individually judged by the respondents and might have varied.

- Two-fifths of the midwives had undertaken a course which included diabetes in pregnancy, with $5 \%$ of these having undertaken more than one course.

- The most commonly mentioned university course was from 
Figure 1. Prescribing role of midwives

Q9: Are diabetes medications in pregnancy part of your current scope of prescribing practice?

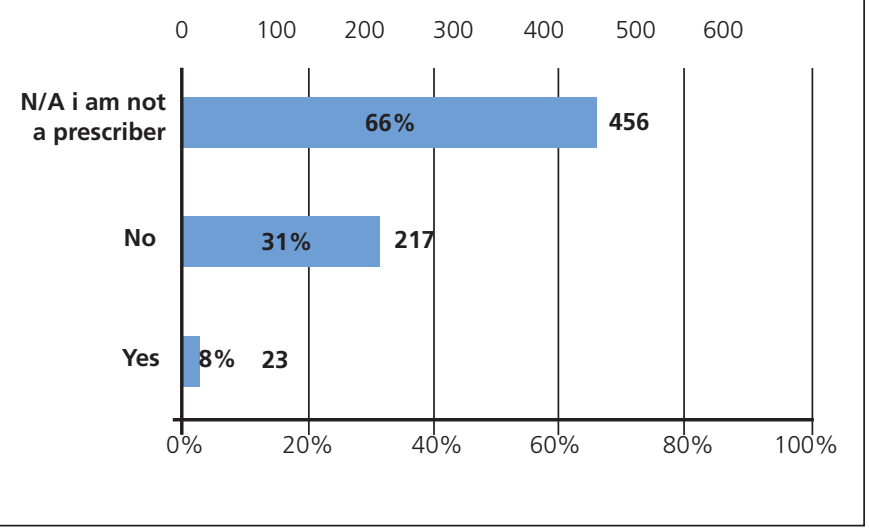

Warwick University followed by King's College London. Warwick ${ }^{15}$ and Cardiff ${ }^{16}$ were the only universities cited that had offered specific standalone 'diabetes in pregnancy' courses.

- Only 3\% of midwives included diabetes medications as part of their prescribing practice. This is made up of 13 DSMs, six midwives who would like more knowledge about diabetes management in pregnancy, one midwife who would like to become a DSM and three who do not wish to be a DSM. Fifty-three DSMs (66\%) are not prescribers (Figure 1).

\section{Midwives' expertise and training needs}

- The survey questioned midwives about a number of topics related to diabetes (see Box 1), their previous training, current level of expertise and desire for training in a range of subject areas (Figures 2 and 3).

- $61 \%$ of the 110 Trusts who responded (out of a total of 130 Trusts with midwifery units where questionnaires were sent) provided training to ensure competent and safe management of pregnant women with diabetes.

- The percentage of midwives who had accessed at least one form of training (on the ward or in clinic from colleagues, via in-house statutory training, self-directed learning, e-learning module, a study day, a short course, a university accredited course or as part of student midwifery training) ranged from just under one quarter (JBDS Guidance 2017) to $91 \%$ (monitoring babies' glucose levels after birth). Just under one-third (30\%) had accessed 'insulin initiation' training and just over one-third (36\%) 'insulin titration' training.

- The most commonly cited form of learning was 'on the ward or in clinic from my colleagues' (31\%) followed by 'as part of my midwifery training' (24\%). The least cited ways of learning were 'via e-learning' and 'on a university accredited course' (both $5 \%$ ), followed by 'on a study day or short course' (8\%).

- The percentage of midwives who rated themselves as satis-
Box 1 Diabetes in pregnancy topics used in questionnaire

Awareness of diabetic ketoacidosis

Awareness of the psychological effect that diabetes can have on pregnant women

Blood ketone testing

Causes and physiology of gestational diabetes

Conducting an antenatal review appointment with an insulin user

Diagnosis including the importance and understanding of the Glucose Tolerance Test

Dietary advice for gestational diabetes

Educating women on the future risk of gestational diabetes and type 2 diabetes

Future pregnancy planning

Gestational diabetes prevention

Importance of breast feeding for mother and baby

Initiation of treatment, including diet, for high glucose levels

Inpatient management of diabetes during pregnancy (excluding birth)

Insulin initiation

Insulin titration

Joint British Diabetes Societies (JBDS) guidance on diabetes management during pregnancy, labour and birth

Management of gestational diabetes - including types of insulin

Management of glucose levels after steroid treatment in women with diabetes

Management of hypos

Management of oral diabetes medication

Managing variable rate intravenous insulin infusion in pregnancy and delivery

Medical aspects of glucose metabolism during pregnancy and postnatal period

Monitoring babies' glucose levels after birth

Monitoring of gestational diabetes

NICE guidance on diabetes management during pregnancy, labour and birth

Postnatal assessment including insulin management and long-term diabetes status

Providing pre-conception advice for women with diabetes

Risks and complications of diabetes during pregnancy, labour and birth

Screening for gestational diabetes

Understanding of different types of diabetes

Understanding the legal aspects of driving (insulin use and hypos)

factory in each of a number of competencies ranged from $15 \%$ (insulin initiation) to $56 \%$ (managing variable rate intravenous insulin infusion in pregnancy and delivery).

- The percentage of midwives who rated their knowledge as 'excellent' or 'very good' ranged from 6\% (JBDS Guidance) to $52 \%$ (monitoring babies' glucose levels after birth), increasing to $18-84 \%$, respectively, when including 'good'.

- There is a strong desire for formal accredited training among midwives, ranging from $71 \%$ wanting training in 'insulin initiation' to $88 \%$ wanting education about 'medical aspects of glucose metabolism during pregnancy and the postnatal period'. 
Figure 2. Perceived competence of midwives

Q10: How would you rate your competence in the following areas of diabetes treatment, medicines management and diet in pregnancy?

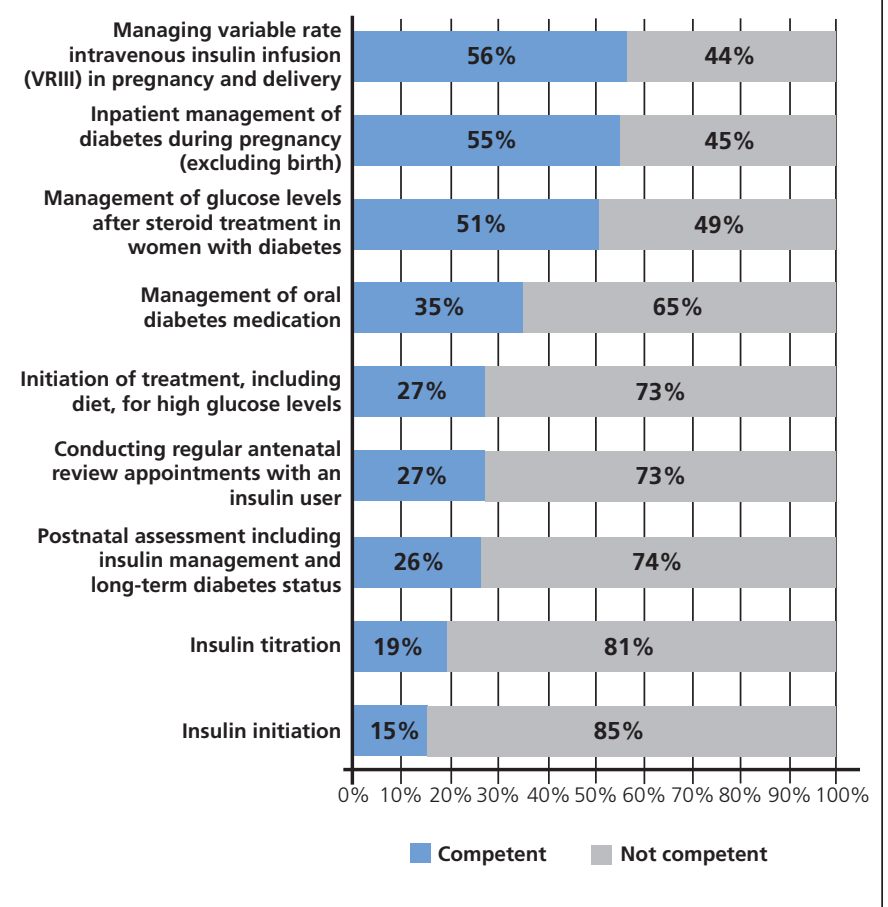

- Previous training and level of competence do not appear to impact significantly on the midwives' desire for training.

- Midwives who would like to become DSMs and those who want to know more about diabetes are the groups who said 'yes' most often to training. The current DSMs have a slightly different focus on what training they would like, which could be characterised as more specialist and less 'routine'.

\section{Insulin initiation and training in more depth}

The characteristics of those who would like formal training in insulin initiation and titration were analysed in more depth (Figure 4). The findings were:

- Of the DSMs, 79\% wanted training in insulin initiation; 92\% of midwives who wanted to be a DSM wanted training in insulin initiation.

- Of those who have a Masters degree and university-accredited training that includes diabetes management in pregnancy, $77 \%$ would like training in insulin initiation and $79 \%$ training in titration.

- Of those who have diabetes medications as part of their prescribing practice, 59\% want training in insulin initiation and titration.

- Of those who rated themselves as 'competent', 75\% would like training in insulin initiation and $78 \%$ would like training in insulin titration.

- Of those who rated themselves as 'not competent', 70\%
Figure 3. Expertise and knowledge

Q13, Q16, Q19: How would you rate your expertise/knowledge in the following areas?

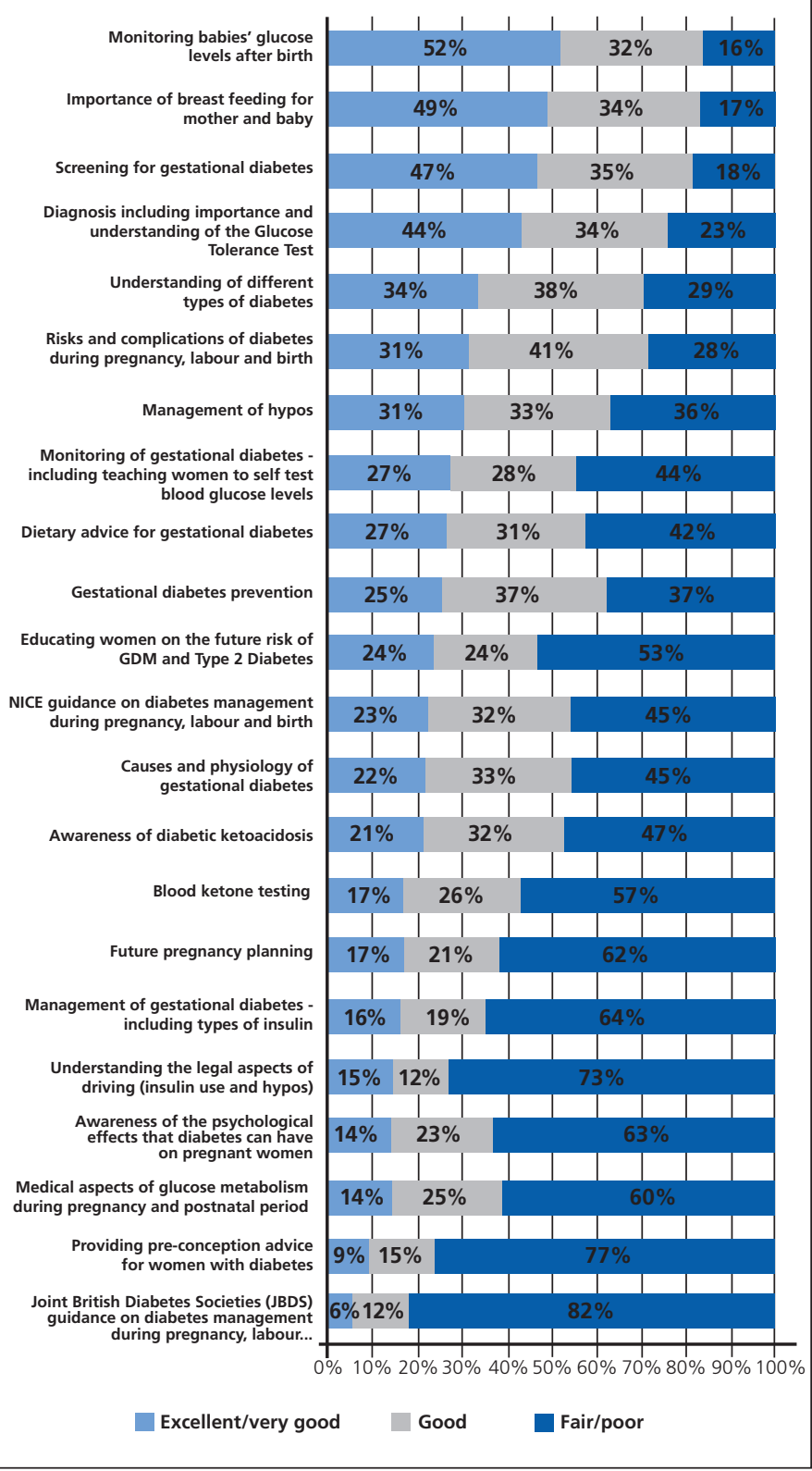

would like training in insulin initiation and $73 \%$ would like training in insulin titration.

\section{Support given by the Diabetes Specialist Team (DST) to midwives}

- $70 \%$ of the midwives find it easy or very easy to obtain advice from the DST. However, 10\% reported that it was 'difficult' or 'very difficult' to obtain advice, including $8 \%$ of the DSMs who found it 'difficult'.

- $40 \%$ of the midwives reported not receiving any training from their DST. This includes $22 \%$ of DSMs. Of those who 
Figure 4. Desire for formal training

Q12, Q15, Q18, Q21: Would you like formal (accredited) training in the following areas?

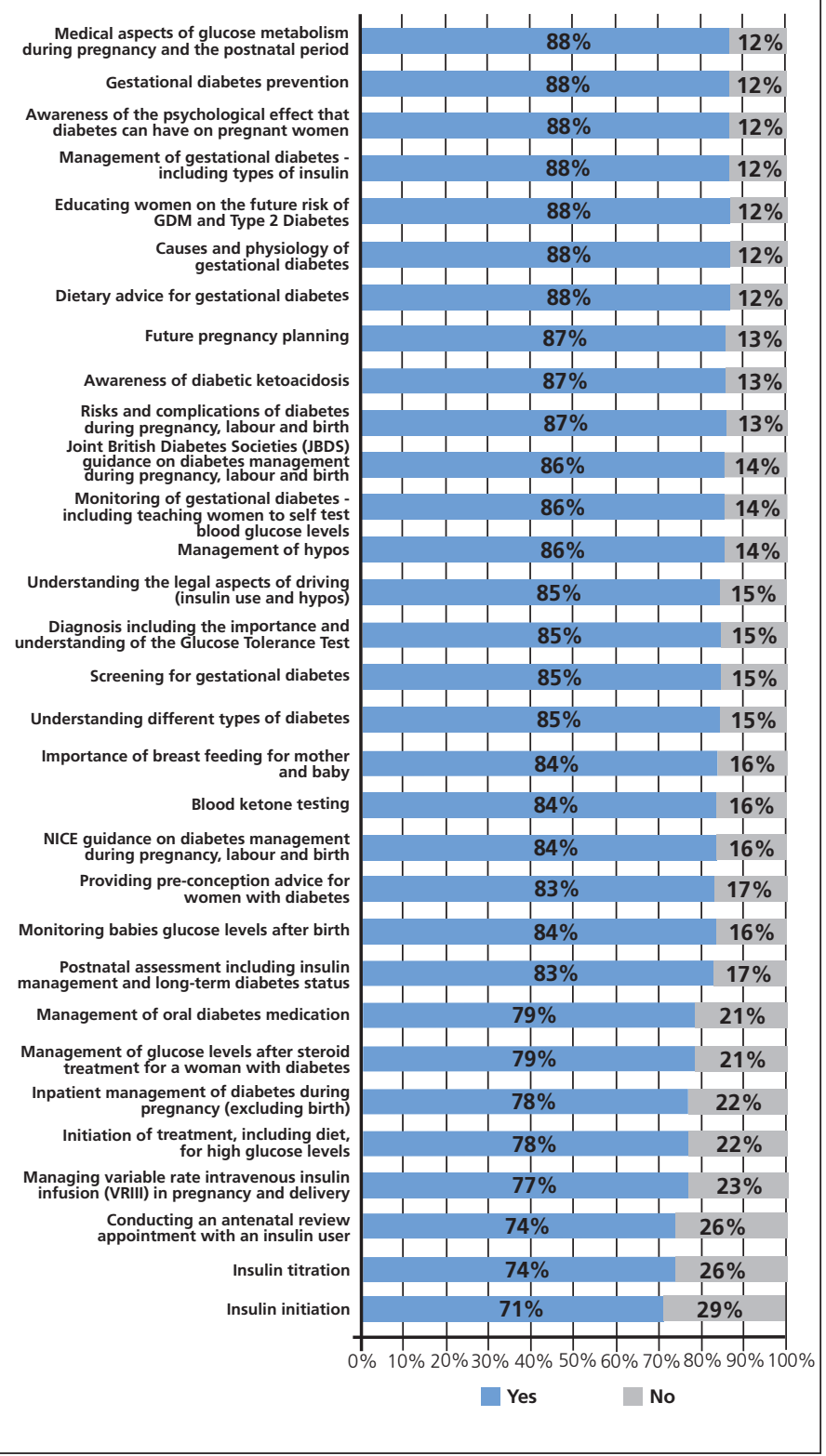

did receive training, this was mostly received on an annual basis with the training lasting generally 30 minutes or one hour.

\section{Other comments on training}

- Two-thirds of the midwives reported that they could use study leave to attend the training. This increased to $71 \%$ for DSMs and $82 \%$ for those who do not want to be DSMs, but was lower for those who want to become a DSM/want to know more about diabetes in pregnancy (63\% and 64\%, respectively).
- $\quad$ The midwives reported that they would go to a range of professionals for advice, with the most frequently cited being a DSM (26\%) followed by a consultant obstetrician (21\%). DSMs would more often seek advice from a consultant diabetologist/endocrinologist (27\%) than other midwives would $(13 \%)$, as would higher bands.

\section{Discussion}

The survey was completed by 698 respondents, a response rate of $2.3 \%$ from a broad cross-section of midwives. There are currently 21,900 practising midwives in the UK and $3.18 \%$ responded to the questionnaire.

Midwives are supported by a range of professionals who they appear happy to contact for advice. Although it is a little concerning that a small proportion of them reported that it was 'difficult' or 'very difficult' to obtain advice, this may be a 'system' problem rather than a training issue.

It is evident from the responses that midwives are very interested in knowing more about diabetes in pregnancy. There is a strong desire for formal accredited training among the midwives.

Midwives who would like to become DSMs and those who want to know more about diabetes are the groups which said 'yes' most often to training. The current DSMs have a slightly different focus on what training they would like compared with non-DSMs, and this tends to be at the more specialist end of the spectrum. It is clear that there is considerable heterogeneity nationally in the availability of DSMs and the activities they perform. This could be historical in some Trusts and would vary depending upon the support available from the DSTs locally.

Only 23 midwives (3\%) include diabetes medications as part of their prescribing practice; 13 of them are DSMs, leaving 53 DSMs who are not prescribers. It would be beneficial to understand in more detail the benefits of midwives being able to prescribe and how midwives obtain prescribing status, in order to decide if this would be an essential element of a training programme.

The availability of study leave for training was variable and how to enable midwives to access the training programme will need to be considered in any future design stage. The barriers to engage with the training (time, content, relevance or any other factor) can be explored in more detail as the programme is rolled out. By an iterative process, it is possible to refine the education and training programme individualised to local needs. Areas like pre-conception advice were identified as needing attention and can be addressed as a priority as the programme content develops.

The midwives' responses show how important they believe it is to have a DSM or similar taking an active role in diabetes management, particularly for pregnant women with diabetes, but also for midwives and NHS Trusts.

Forty percent of midwives reported having attended a university course that includes diabetes in pregnancy. The most commonly cited course attended was from Warwick University. Warwick and Cardiff were the only universities cited that had offered specific standalone 'diabetes in pregnancy' courses. It 
would be helpful to have more information about these courses in terms of curriculum, cost and location.

Limitations in carrying out the survey in this way are recognised. The response rate was quite low and may reflect the training desires of a group of midwives who are already interested in diabetes and want to upskill further. It could be argued that results from a survey with such a low response rate cannot be used to drive major changes. It must be pointed out that the survey was sent to all the midwives on the database of the RCM, many of whom were not active and may explain the poor response rate. The writing group strongly feels that, given the large absolute number of responses received, the conclusions drawn are justified. Further education and training of midwives will undoubtedly improve patient care of pregnant women with diabetes. The danger of providing courses to an unwilling group can always be mitigated by assessing the uptake of initial elearning courses before developing more elaborate courses. The survey validity is also compromised by some possible duplicates in entries and the self-selecting respondents which may bring a certain level of bias. There were also a few technical issues immediately after the launch of this survey which resulted in difficulties in progressing beyond questions 28 and 33 for some respondents. This may have resulted in fewer completed survey responses from those who could not progress beyond these questions until these issues were fully resolved.

While a majority of midwives with experience of insulin initiation and titration rated themselves as competent and confident, they also expressed a desire for more training. This may reflect the quality of some aspect of the training they had received or the need for more formal training and accreditation to demonstrate competence in these areas in order to re-validate their prescribing practice. Alternatively, the question might have been differently interpreted by these respondents who might have wanted to train in actual injection teaching and practical aspects of insulin treatment in addition to their competency in selecting the type of insulin and dose adjustments for a particular patient.

\section{Conclusion}

The recent National Pregnancy in Diabetes Audit and MBRRACEUK perinatal confidential enquiry into stillbirths have found significant deficiencies in the care received by pregnant women with diabetes in spite of excellent guidelines from NICE and JBDS-IP.

Midwives play a pivotal role in the care of pregnant women with diabetes from pre-conception to antenatal care with support from the DST. Midwives are in the ideal position to support pregnant women with diabetes, to ensure they are on the correct pathway of care at the right time and to empower the women to self-care and manage the risks associated with diabetes in pregnancy.

Ensuring that all midwives have an appropriate level of training in diabetes may be one of a number of actions needed to support the reduction in stillbirths, complication rates and poor outcomes.

The survey responses confirm that midwives are well supported by the DST and their DSM colleagues. They report higher

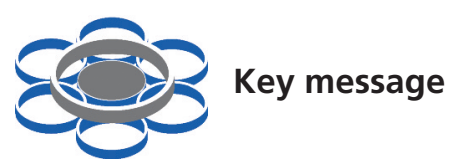

- Over $85 \%$ of midwives recognise the need for education to improve their care of pregnant women with diabetes.

- The need for education is felt by all midwives, and not only by those who work in a more specialised role with women with diabetes. The educational needs of the various groups require courses with different content, even when dealing with the same subject matter.

- Some midwives have completed a range of different diploma, degree and masters level courses, which included elements on the management of diabetes in pregnancy.

- Many midwives felt they need further accredited training, especially in insulin initiation and titration. The perceived need for further training was independent of their self-expressed confidence and competence.

- Midwives of all backgrounds believe that diabetes specialist midwives provide a higher standard of care and improved outcomes, as well as giving better continuity and consistency of care.

- A strong case can be made for three levels of training: (a) general training on the principles and diagnosis of diabetes as well as initial management; (b) extended diabetes training suitable for midwives working in high-risk areas who are not specialists in diabetes; (c) in-depth training for diabetes specialist midwives in the supervision and management of diabetes management including insulin initiation and treatment, which would give them accredited qualifications in the non-medical prescribing of diabetes medications including insulin and supporting joint diabetes antenatal clinics.

competency levels where they have had access to training. However, regardless of previous training and competency rating, there is a strong desire for training across all the areas of diabetes care.

Consideration will need to be given to the details of course content and competency, but initial conclusions are that it could be divided into a programme of three levels rather than the two originally hypothesised:

- Level 1: General diabetes training - for all midwives. General diabetes management including early diagnosis of gestational diabetes (GDM), risk factors, early referral and follow-up.

- Level 2: Extended diabetes training - for those midwives wanting more depth or who wish to become a DSM. 
- Level 3: Specialist DSM diabetes training - in-depth specialist training for those who are DSMs or have completed level 2, and would like to supervise diabetes management including insulin initiation and titration.

Each of these may require a different approach to provision, with Level 1 potentially offered as a set of accredited e-learning modules, Level 2 training potentially offered as a mix of face-toface course and e-learning and Level 3 being university accredited requiring attendance and a local mentor/supervisor. The DCT should work with the RCM to ensure that all courses fulfil the requirements for RCM accreditation.

Each level of the training could be provided by a different education provider - the DCT, the RCM, existing training organisations or universities, all of which will have different benefits and financial implications and will need to be explored in detail.

When considering how to take this forward, it is important to ensure that the midwives and their NHS Trusts will see a clear benefit/impact. It is also important to take into account the current financial climate in the NHS and ensure that the programme is developed, provided and funded in a way that supports NHS Trusts to enable their midwives to access it.

\section{Recommendations}

1. Undertake further research arising from the results of the survey including:

a. The availability of existing diabetes in pregnancy courses. This should include university-accredited modules, both standalone modules and those that are part of a degree/ Masters course as well as non-accredited courses.

b. Find out more about the process for midwives to become non-medical prescriberd. Ascertain the benefits for midwives being able to prescribe diabetes medications: the benefits for the midwives themselves, the mothers and babies, the wider team/s, the Trust and in terms of outcomes.

2. Develop a competency framework for diabetes that is specific to the midwife role in caring for women with pre-existing or gestational diabetes throughout the care pathway from pre-conception to antenatal care. Work with RCM and TREND-UK to ensure accreditation.

3. Develop a specification for a midwife training programme for diabetes management in pregnancy, taking into account an appraisal of the options of potential design and delivery methods, course content including refresher, cost appraisal, funding options, accreditation options, intellectual property considerations and benefits/impact appraisal.

\section{Conflict of interest None}

Funding The project was funded by Diabetes Care Trust (DCT).

\section{References}

1. National Institute for Health and Care Excellence. Diabetes in pregnancy: management of diabetes and its complications from preconception to the postnatal period. 2015. http://www.nice.org.uk/ guidance/ng3 (accessed 18 April 2018).

2. Dornhurst A, Banerjee A. In: Holt R, Cockram C, Flyvbjerg A, Goldstein B, editors. Textbook of Diabetes, 4th edition. Wiley-Blackwell, 2010. 2011; Chapter 53: 888-921.

3. Noctor E, Dunne F. A Practical guide to pregnancy complicated by diabetes. Diabetes Primary Care 2014;16:146-53.

4. NHS. National Diabetes in Pregnancy Audit 2017. http:// digital.nhs.uk/catalogue/PUB30109 2017 (accessed 18 April 2018)

5. Dashora U, Rafique S, Tharayil G, Jones S, Castro E, Sathiskumar P. The feasibility and impact of implementing NICE guidance on diabetes control during delivery. Br J Diabetes 2017;17:100-6. https://doi.org/10.15277/bjd.2017.137

6. Murphy, HR, Bell R, Cartwright C, et al. Improved pregnancy outcomes in women with type 1 and type 2 diabetes but substantial clinic-to-clinic variations: a prospective nationwide study. Diabetologia 2017;60:1668. https://doi.org/10.1007/s00125-017-4314-3

7. Feig DS, Donovan LE, Corcoy R, et al. Continuous glucose monitoring in pregnant women with type 1 diabetes (CONCEPTT): a multicentre international randomised controlled trial. Lancet 2017;390:2347-59. https://doi.org/10.1016/S0140-6736(17)32400-5

8. Public Health England. Atlas of Variation. http://fingertips.phe.org.uk/ profile/atlas-of-variation (accessed 13 Feb 2018)

9. Joint British Diabetes Societies-In Patient. Management of glycaemic control in pregnant women with diabetes on obstetric wards and delivery units. http://www.diabetologists-abcd.org.uk/JBDS/JBDS_Pregnancy_final_ 18082017.pdf (accessed 14 Dec 2017).

10. Royal College of Midwives. Lead midwife in diabetes: standards, roles and competencies. NHS Diabetes, 2010. https://www.rcm.org.uk/ sites/default/ files/NHSDAKC_0002_A4Midwivesbrochure_5.pdf

11. National Institute for Health and Care Excellence. Type 2 diabetes in adults: management. 2015. https://www.nice.org.uk/guidance/ng28 (accessed 18 April 2018).

12. National Institute for Health and Care Excellence. Diabetes in adults. 2016. https://www.nice.org.uk/guidance/qs6/chapter/quality-statement-7-inpatient-care-for-adults-with-type-1-diabetes (accessed 18 April 2018).

13. Dashora U, Davies HA, Bennett $S$, et al, on behalf of the Association of British Clinical Diabetologists $(A B C D)$. Diabetes care in pregnancy. A midwife education needs analysis. http://www.diabetologists-abcd.org.uk/Research/DCT_report_final_05012018.pdf. 2018 (accessed 17 Oct 2018).

14. Nash M. A mixed methods approach to exploring mental health nurses' diabetes education and skills needs. DProf Thesis, Middlesex University, 2014 http://eprints.mdx.ac.uk/13468/.

15. Warwick Medical School. Diabetes in pregnancy. https://www2.warwick .ac.uk/fac/med/study/cpd/module_index/mh907/ (accessed 18 April 2018).

16. Cardiff University. Postgraduate diabetes education. http://www.diabetesdiploma.cf.ac.uk/programmes/modules.php (accessed 18 April 2018). 
Dr Huw Alban Davis, Chair, Diabetes Care Trust.

Umesh Dashora, Consultant Diabetologist, Conquest Hospital, Hastings. Umesh is the first lead author of the Joint British Diabetes Society's guidelines on perinatal diabetes management.

Shelley Bennett, founder of Circle D, a support network for people aged 18-30 with diabetes that operates through Facebook, the website, meetings and events.

Anne Goodchild, Diabetes Specialist Nurse. Anne is the founder of PITstop and designed this highly successful course to accredit nurses in initiating injectable treatments for people with diabetes.

Julia Hugason-Briem, project manager and Director of Briem Consulting Ltd. Julia has extensive experience in the health commissioning and service improvement, including the diabetes commissioning field as well as audit and survey.

Gail Johnson, Education Advisor, Royal College of Midwives. Gail has a particular interest in the provision of e-learning.

Abigail Kitt, Senior Quality Improvement Lead (Diabetes), South East Clinical Network, NHS England

Annette Schreiner, Consultant Obstetrician and Medical Director at Darent Valley Hospital (recently retired). She contributed to and taught the University of Brighton Masters module in diabetes in pregnancy.

Diane Todd, Diabetes Specialist Midwife, Leicester University Hospitals. Di is a member of the NICE Guideline Group for Diabetes in Pregnancy and was a contributing member of NHS Diabetes' report on "Lead Midwife in Diabetes: Standard Role and Competencies".

Dr Jennifer Yiallouros, a researcher and Director of Qualjenuity, a research consultancy analysing qualitative health data. Jen is also a Research Associate at the University of Leicester. 


\section{How many midwives does your Trust employ?}

Please state number of individuals and WTEs for each grade of midwife you employ including vacancies.

\begin{tabular}{|l|l|l|}
\hline Grade/ Band & WTE & Individuals \\
\hline & & \\
\hline & & \\
\hline & & \\
\hline & & \\
\hline
\end{tabular}

2. How many midwives are involved in the care of pregnant women with diabetes? Please state number of individuals and WTEs for each grade of midwife you employ including vacancies.

\begin{tabular}{|l|l|l|}
\hline Grade/ Band & WTE & Individuals \\
\hline & & \\
\hline & & \\
\hline & & \\
\hline & & \\
\hline & & \\
\hline
\end{tabular}

3. Is there a joint clinic for management of pregnant women with diabetes?

$\mathrm{Y} / \mathrm{N}$ 
Appendix 2 Freedom of Information questions continued

If yes, which healthcare professionals are involved?

\begin{tabular}{|l|l|}
\hline Health Care Professional & $\mathbf{Y / N}$ \\
\hline Consultant obstetrician & \\
\hline Consultant diabetologist & \\
\hline Diabetes Specialist Nurse & \\
\hline Diabetes Specialist Midwife & \\
\hline Diabetes specialist Dietician & \\
\hline
\end{tabular}

Other (Please specify)

4. What competencies are those midwives caring for pregnant women with diabetes working towards? Please describe/ attach details

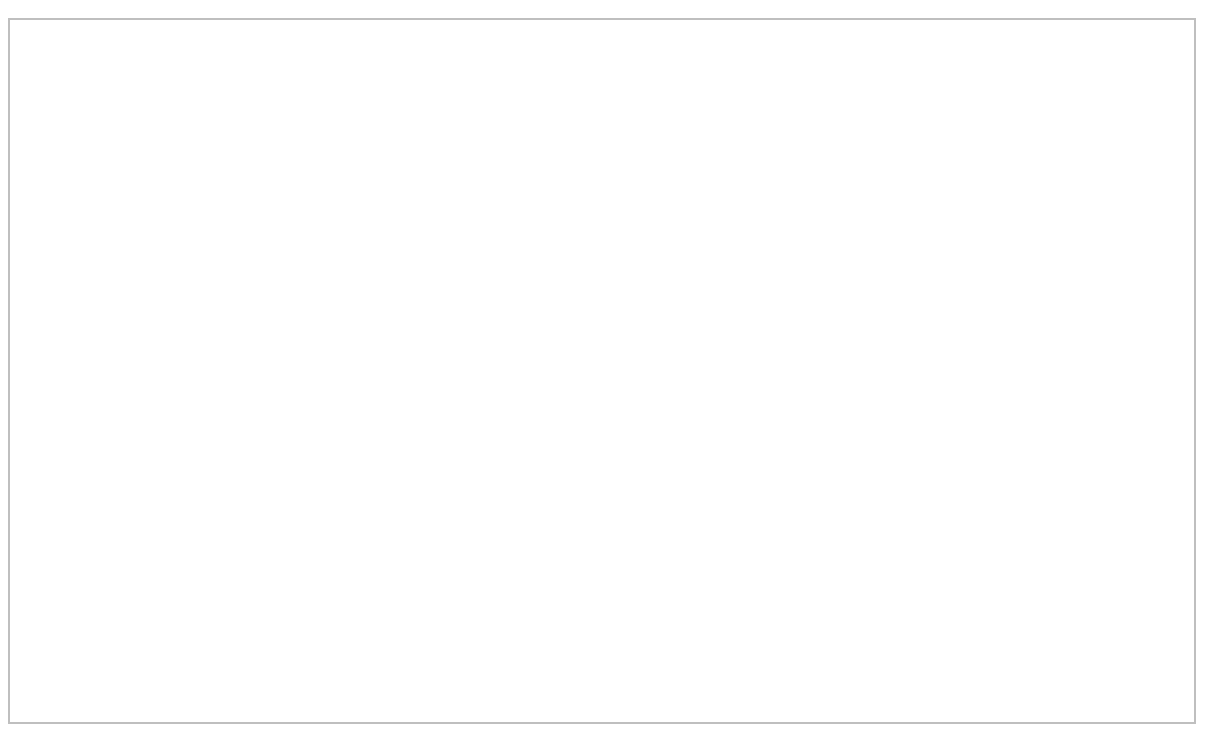

5. Do you have any training in place to ensure these competencies?

$\mathrm{Y} / \mathrm{N}$

Continued. 
Appendix 2 Freedom of Information questions continued

If yes, please can you provide details of the training

- What is covered in the training?

- Who provides the training?

- Is the training university accredited?

- How many midwives attended the training in each of the last three years?

- Please provide documentation if available

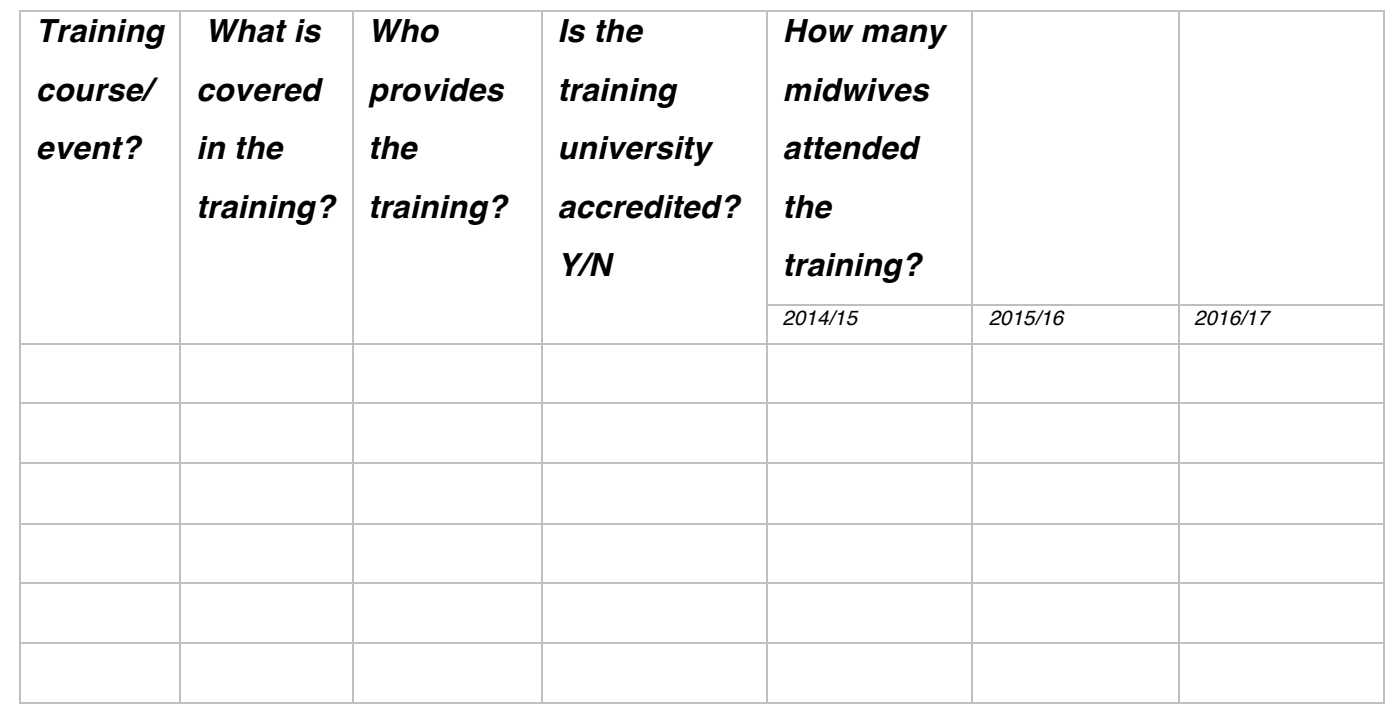

6. Are any midwives involved in

\begin{tabular}{|l|l|}
\hline & $\mathbf{Y / N}$ \\
\hline Management of oral diabetes medication & \\
\hline Insulin initiation & \\
\hline Insulin titration & \\
\hline
\end{tabular}


7. We would like to contact the diabetes specialist midwife or the midwife responsible for the overall care of pregnant women with diabetes. Please provide contact details:

Name

Title

Email

Phone 


\section{Training Needs Survey}

Understanding the training needs of midwives in relation to the care of pregnant women with diabetes

(Please note where diabetes is stated this includes Type 1, Type 2 and GDM unless otherwise indicated)

Welcome to our survey - this survey is open to all qualified midwives

Thank you for participating in our survey, your feedback is important.

We would welcome responses from all qualified midwives. We would also welcome responses from those working as a Diabetes Specialist Midwife, a midwife with a special interest in diabetes or similar, or a midwife who would like to develop this expertise.

Please tell us more about yourself

1. How many years have you been qualified as a midwife?

$0-4$ years

$5-9$ years

10-14 years

$15+$ years

2. Did you train as a nurse prior to becoming a midwife?

Yes

No

\section{What band are you employed at?}

Band 5

Band 6

Band 7

Band 8a

Band $8 b$

Band 8c

Band 8d

4. Which areas do you work in? (Please tick all that apply)

Antenatal clinic

Antenatal ward

Labour ward and birth centre

Community

Education and research

Other (please specify)

5. What additional responsibilities do you have in your role as a midwife? Please tick all that apply.

Staff management

Finance/ budget management

Quality improvement 
Safety

Risk

Teaching/training

Audit

I do not have any additional responsibilities

Other, please specify

Please tell us more about your role in managing diabetes in pregnancy

\section{At what level do you currently provide care to pregnant women with} diabetes?

I do not currently provide care to pregnant women with diabetes

Providing high risk and low risk care

Providing low risk care only

Other (please specify)

7. Are you currently or would like to become a Diabetes Specialist Midwife, Link Midwife, High Risk Midwife, Midwife with a special interest in diabetes or similar?

Yes, I am a DSM or similar

No, I am not a DSM or similar, but I would like to be

No, I am not a DSM or similar, but I would like more knowledge about diabetes management in pregnancy

No, I am not DSM or similar, and do not wish to be

\section{Have you completed a university course that includes diabetes management} in pregnancy?

\begin{tabular}{|l|l|l|}
\hline & Yes & No \\
\hline Masters Level qualification & & \\
\hline Degree Level qualification & & \\
\hline $\begin{array}{l}\text { Other university accredited course or } \\
\text { module }\end{array}$ & & \\
\hline $\begin{array}{l}\text { If yes, please give further details } \\
\text { including: name of university, title of } \\
\text { course, number of credits }\end{array}$ & & \\
\hline
\end{tabular}

Please tell us about your expertise and training need in diabetes treatment and medicines management

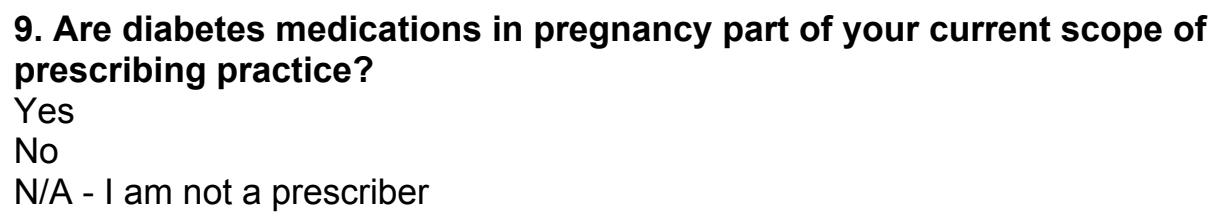

9. Are diabetes medications in pregnancy part of your current scope of prescribing practice?

Yes

No

N/A - I am not a prescriber

10. How would you rate your competence in the following areas of diabetes treatment, medicines management and diet in pregnancy? 


\begin{tabular}{|l|l|l|}
\hline & Competent & $\begin{array}{l}\text { Not } \\
\text { Competent }\end{array}$ \\
\hline $\begin{array}{l}\text { Conducting regular antenatal review appointments } \\
\text { with an insulin user }\end{array}$ & & \\
\hline $\begin{array}{l}\text { Initiation of treatment, including diet, for high glucose } \\
\text { levels }\end{array}$ & & \\
\hline Management of oral diabetes medication & & \\
\hline Insulin initiation & & \\
\hline Insulin titration & & \\
\hline $\begin{array}{l}\text { Management of glucose levels after steroid treatment } \\
\text { in women with diabetes }\end{array}$ & & \\
\hline $\begin{array}{l}\text { Inpatient management of diabetes during pregnancy } \\
\text { (excluding birth) }\end{array}$ & & \\
\hline $\begin{array}{l}\text { Managing variable rate intravenous insulin infusion } \\
\text { (VRIII) in pregnancy and delivery }\end{array}$ & & \\
\hline $\begin{array}{l}\text { Postnatal assessment including insulin management } \\
\text { and long-term diabetes status }\end{array}$ & & \\
\hline
\end{tabular}

11. Have you had any training in the following areas? (Please tick all boxes that are relevant)

\begin{tabular}{|c|c|c|c|c|c|c|c|c|}
\hline & $\begin{array}{l}\text { Yes, on } \\
\text { the } \\
\text { ward or } \\
\text { in clinic } \\
\text { from } \\
\text { my } \\
\text { colleag } \\
\text { ues }\end{array}$ & $\begin{array}{l}\text { Yes, } \\
\text { via in- } \\
\text { house } \\
\text { statutor } \\
\text { y } \\
\text { training }\end{array}$ & $\begin{array}{l}\text { Yes, } \\
\text { via } \\
\text { self- } \\
\text { directe } \\
\text { d } \\
\text { learnin } \\
g\end{array}$ & $\begin{array}{l}\text { Yes, } \\
\text { via an } \\
\text { e- } \\
\text { learnin } \\
\text { g } \\
\text { module }\end{array}$ & $\begin{array}{l}\text { Yes, } \\
\text { on a } \\
\text { study } \\
\text { day } \\
\text { or } \\
\text { short } \\
\text { cours } \\
\text { e }\end{array}$ & $\begin{array}{l}\text { Yes, on } \\
\text { a } \\
\text { universit } \\
\text { y } \\
\text { accredit } \\
\text { ed } \\
\text { course }\end{array}$ & $\begin{array}{l}\text { Yes, as } \\
\text { part of } \\
\text { my } \\
\text { student } \\
\text { midwifer } \\
\text { y } \\
\text { training }\end{array}$ & No \\
\hline \multicolumn{9}{|l|}{$\begin{array}{l}\text { Conducting an } \\
\text { antenatal review } \\
\text { appointment with } \\
\text { an insulin user }\end{array}$} \\
\hline \multicolumn{9}{|l|}{$\begin{array}{l}\text { Initiation of } \\
\text { treatment, } \\
\text { including diet, for } \\
\text { high glucose } \\
\text { levels }\end{array}$} \\
\hline \multicolumn{9}{|l|}{$\begin{array}{l}\text { Management of } \\
\text { oral diabetes } \\
\text { medication }\end{array}$} \\
\hline \multicolumn{9}{|l|}{ Insulin initiation } \\
\hline Insulin titration & & & & & & & & \\
\hline $\begin{array}{l}\text { Management of } \\
\text { glucose levels }\end{array}$ & & & & & & & & \\
\hline
\end{tabular}

Continued. 


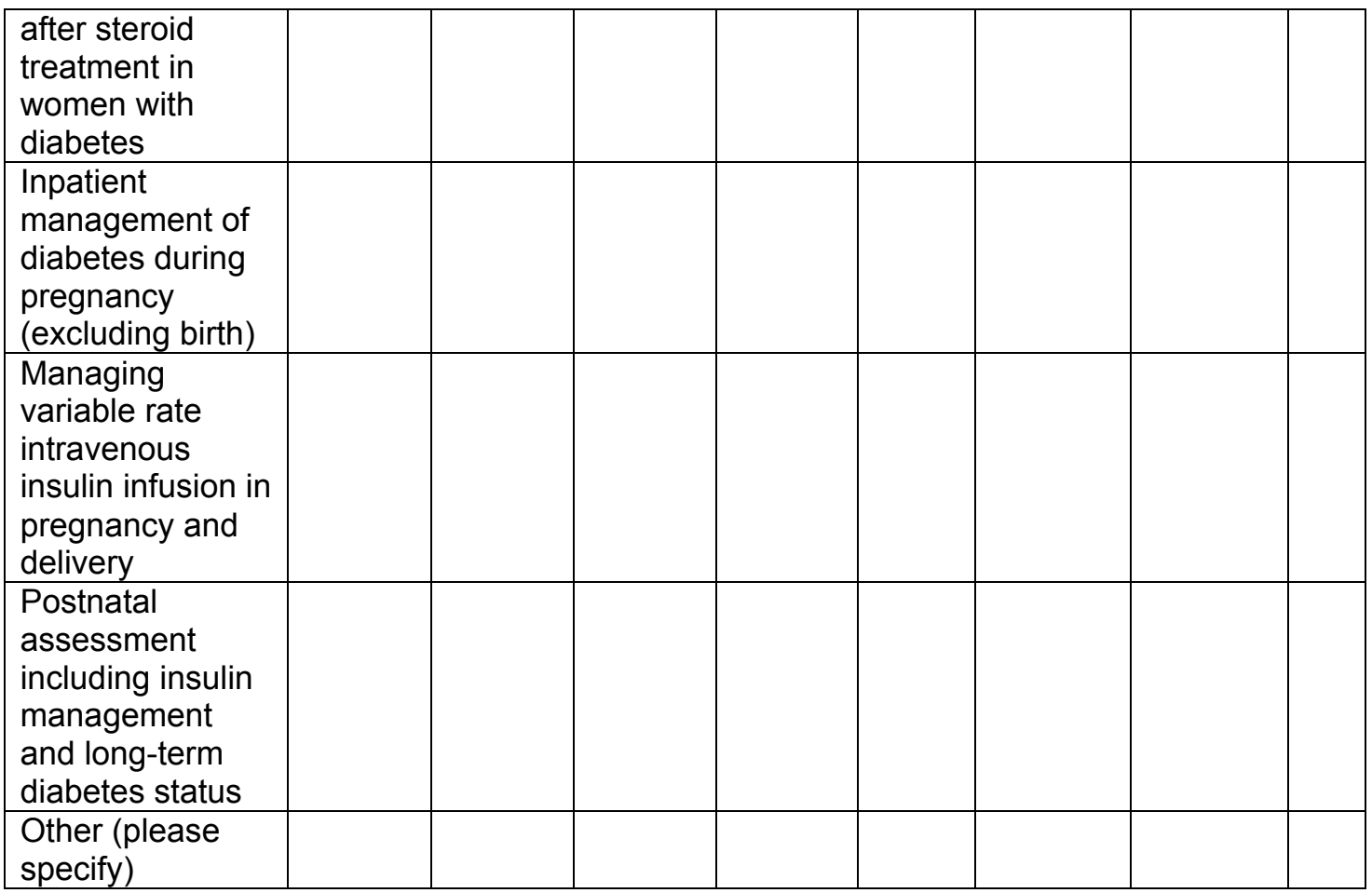

12. Would you like formal (accredited) training in the following areas:

\begin{tabular}{|l|l|l|}
\hline & Yes & No \\
\hline Conducting an antenatal review appointment with an insulin user & & \\
\hline Initiation of treatment, including diet, for high glucose levels & & \\
\hline Management of oral diabetes medication & & \\
\hline Insulin initiation & & \\
\hline Insulin titration & & \\
\hline $\begin{array}{l}\text { Management of glucose levels after steroid treatment for a } \\
\text { woman with diabetes }\end{array}$ & & \\
\hline $\begin{array}{l}\text { Inpatient management of diabetes during pregnancy (excluding } \\
\text { birth) }\end{array}$ & & \\
\hline $\begin{array}{l}\text { Managing variable rate intravenous insulin infusion in pregnancy } \\
\text { and delivery }\end{array}$ & & \\
\hline $\begin{array}{l}\text { Postnatal assessment including insulin management and long- } \\
\text { term diabetes status }\end{array}$ & & \\
\hline If you answered no to any of the above, please specify why not & & \\
\hline
\end{tabular}

13. How would you rate your expertise/knowledge in the following areas of general diabetes management in pregnancy?

\begin{tabular}{|l|l|l|l|l|l|}
\hline & Excellent & Very Good & Good & Fair & Poor \\
\hline $\begin{array}{l}\text { NICE guidance } \\
\text { on diabetes } \\
\text { management }\end{array}$ & & & & & \\
\hline
\end{tabular}


Appendix 3 Full text of Midwife Survey continued

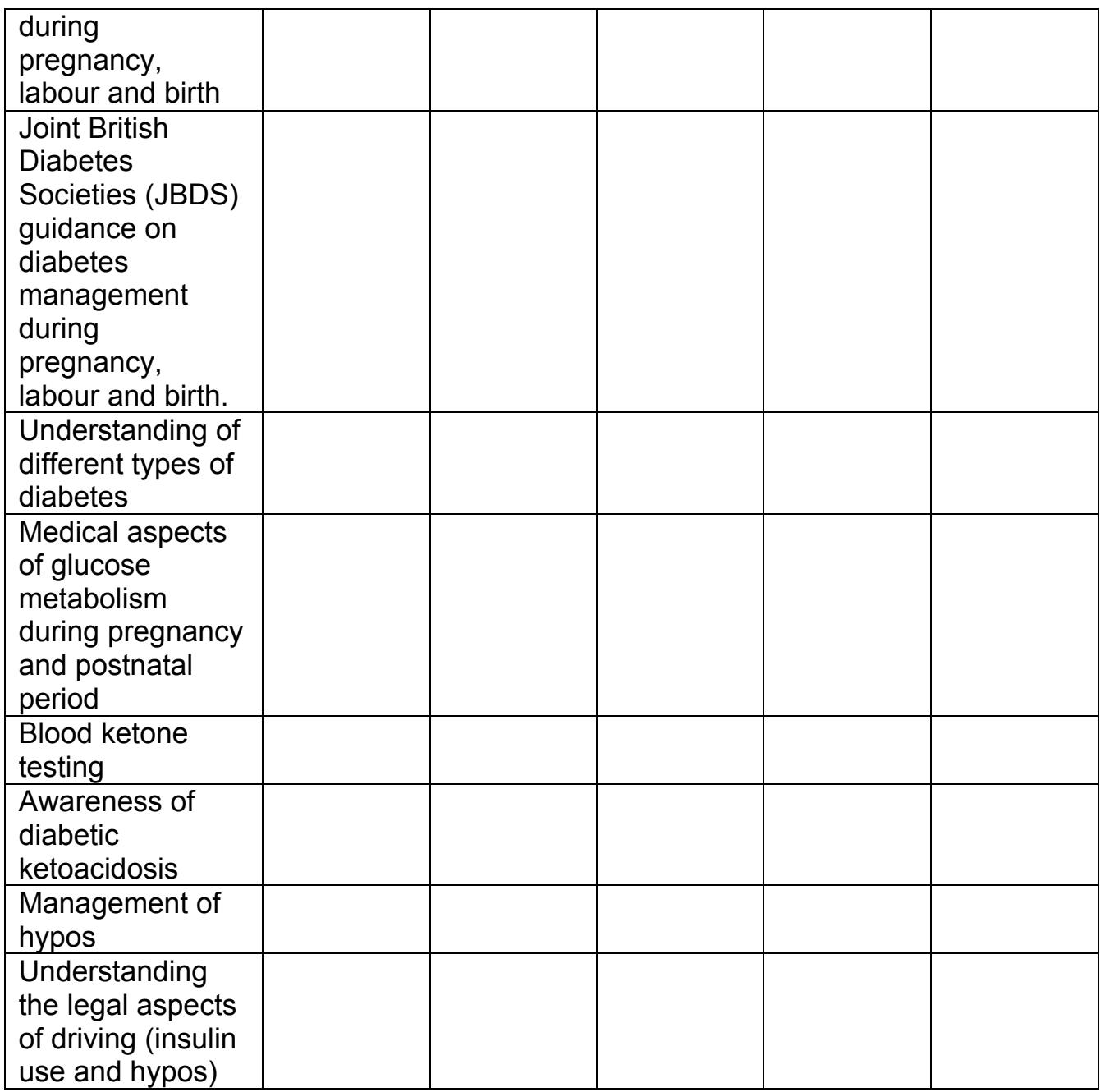

14. Have you had any training, as a midwife, in the following areas? (Please tick all boxes that are relevant)

\begin{tabular}{|c|c|c|c|c|c|c|c|c|}
\hline & $\begin{array}{l}\text { Yes, on } \\
\text { the } \\
\text { ward or } \\
\text { in clinic } \\
\text { from } \\
\text { my } \\
\text { colleag } \\
\text { ues }\end{array}$ & $\begin{array}{l}\text { Yes, } \\
\text { via in- } \\
\text { house } \\
\text { statutor } \\
\text { y } \\
\text { training }\end{array}$ & $\begin{array}{l}\text { Yes, } \\
\text { via } \\
\text { self- } \\
\text { directe } \\
\text { d } \\
\text { learnin } \\
\text { g }\end{array}$ & $\begin{array}{l}\text { Yes, } \\
\text { via an } \\
\text { e- } \\
\text { learnin } \\
\text { g } \\
\text { module }\end{array}$ & $\begin{array}{l}\text { Yes, } \\
\text { on a } \\
\text { study } \\
\text { day } \\
\text { or } \\
\text { short } \\
\text { cours } \\
\text { e } \\
\end{array}$ & $\begin{array}{l}\text { Yes, on } \\
\text { a } \\
\text { universit } \\
\text { y } \\
\text { accredit } \\
\text { ed } \\
\text { course }\end{array}$ & $\begin{array}{l}\text { Yes, as } \\
\text { part of } \\
\text { my } \\
\text { student } \\
\text { midwifer } \\
\text { y } \\
\text { training }\end{array}$ & No \\
\hline $\begin{array}{l}\text { NICE guidance } \\
\text { on diabetes } \\
\text { management } \\
\text { during } \\
\text { pregnancy, }\end{array}$ & & & & & & & & \\
\hline
\end{tabular}

Continued.. 
Appendix 3 Full text of Midwife Survey continued

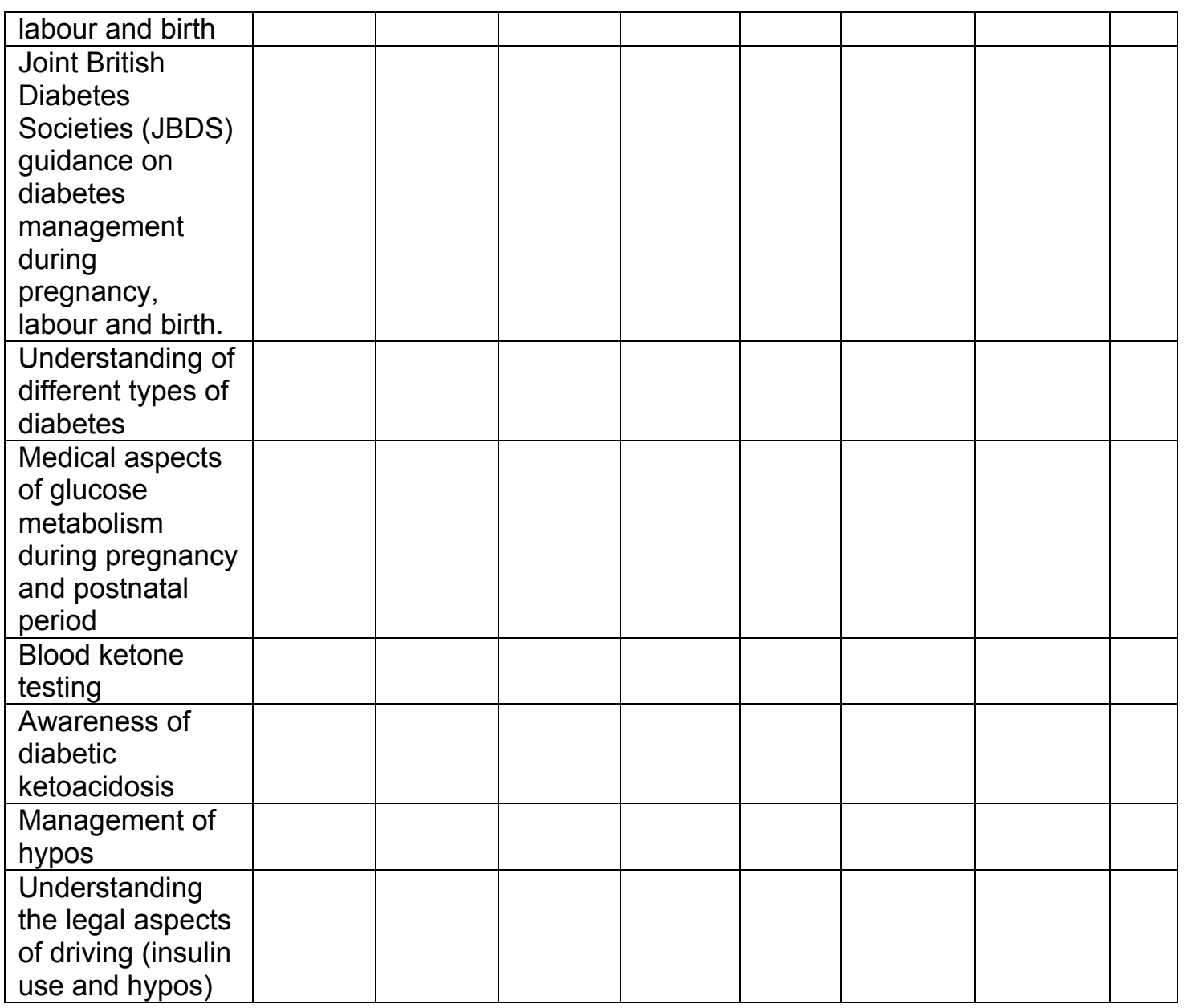

Other (please specify)

15. Would you like formal (accredited) training in any of the following areas?

\begin{tabular}{|l|l|l|}
\hline & Yes & No \\
\hline $\begin{array}{l}\text { NICE guidance on diabetes management during pregnancy, } \\
\text { labour and birth }\end{array}$ & & \\
\hline $\begin{array}{l}\text { Joint British Diabetes Societies (JBDS) guidance on diabetes } \\
\text { management during pregnancy, labour and birth. }\end{array}$ & & \\
\hline Understanding of different types of diabetes & & \\
\hline $\begin{array}{l}\text { Medical aspects of glucose metabolism during pregnancy and } \\
\text { postnatal period }\end{array}$ & & \\
\hline Blood ketone testing & & \\
\hline Awareness of diabetic ketoacidosis & & \\
\hline Management of hypos & & \\
\hline $\begin{array}{l}\text { Understanding the legal aspects of driving (insulin use and } \\
\text { hypos) }\end{array}$ & & \\
\hline
\end{tabular}


If you answered no to any of the above, please specify why not

Please tell us about your expertise and training in gestational diabetes management

16. How would you rate your expertise/knowledge in the following areas of gestational diabetes management?

\begin{tabular}{|l|l|l|l|l|l|}
\hline & Excellent & Very Good & Good & Fair & Poor \\
\hline $\begin{array}{l}\text { Causes and } \\
\text { physiology of } \\
\text { gestational diabetes }\end{array}$ & & & & & \\
\hline $\begin{array}{l}\text { Gestational diabetes } \\
\text { prevention }\end{array}$ & & & & & \\
\hline $\begin{array}{l}\text { Screening for } \\
\text { gestational diabetes }\end{array}$ & & & & & \\
\hline $\begin{array}{l}\text { Diagnosis including } \\
\text { importance and } \\
\text { understanding of the } \\
\text { Glucose Tolerance } \\
\text { Test }\end{array}$ & & & & & \\
\hline $\begin{array}{l}\text { Monitoring of } \\
\text { gestational diabetes - } \\
\text { including teaching } \\
\text { women to self-test } \\
\text { blood glucose levels }\end{array}$ & & & & & \\
\hline $\begin{array}{l}\text { Management of } \\
\text { gestational diabetes - } \\
\text { including types of } \\
\text { insulin }\end{array}$ & & & & & \\
\hline $\begin{array}{l}\text { Dietary advice for } \\
\text { gestational diabetes }\end{array}$ & & & & & \\
\hline
\end{tabular}

17. Have you had any training, as a midwife, in the following areas of gestational diabetes management? (Please tick all boxes that are relevant)

\begin{tabular}{|l|l|l|l|l|l|l|l|l|}
\hline & $\begin{array}{l}\text { Yes, } \\
\text { on the } \\
\text { ward } \\
\text { or in } \\
\text { clinic } \\
\text { from } \\
\text { my } \\
\text { colleag } \\
\text { ues }\end{array}$ & $\begin{array}{l}\text { ves, } \\
\text { house } \\
\text { statuto } \\
\text { ry } \\
\text { trainin } \\
\text { g }\end{array}$ & $\begin{array}{l}\text { Yes, } \\
\text { via } \\
\text { self- } \\
\text { directe } \\
\text { d } \\
\text { learnin } \\
\text { g }\end{array}$ & $\begin{array}{l}\text { Yes, } \\
\text { via an } \\
\text { e- } \\
\text { learnin } \\
\text { g } \\
\text { modul } \\
\text { e }\end{array}$ & $\begin{array}{l}\text { Yes, } \\
\text { on a } \\
\text { study } \\
\text { day } \\
\text { or } \\
\text { short } \\
\text { cours } \\
\text { e }\end{array}$ & $\begin{array}{l}\text { Yes, on } \\
\text { universit } \\
\text { y } \\
\text { accredit } \\
\text { ed } \\
\text { course }\end{array}$ & $\begin{array}{l}\text { Yes, } \\
\text { as part } \\
\text { of my } \\
\text { studen } \\
\text { t } \\
\text { midwif } \\
\text { ery } \\
\text { trainin } \\
\text { g }\end{array}$ & No \\
\hline $\begin{array}{l}\text { Causes and } \\
\text { physiology of } \\
\text { gestational diabetes }\end{array}$ & & & & & & & & \\
\hline $\begin{array}{l}\text { Gestational diabetes } \\
\text { prevention }\end{array}$ & & & & & & & & \\
\hline Screening for & & & & & & & & \\
\hline
\end{tabular}

Continued. 


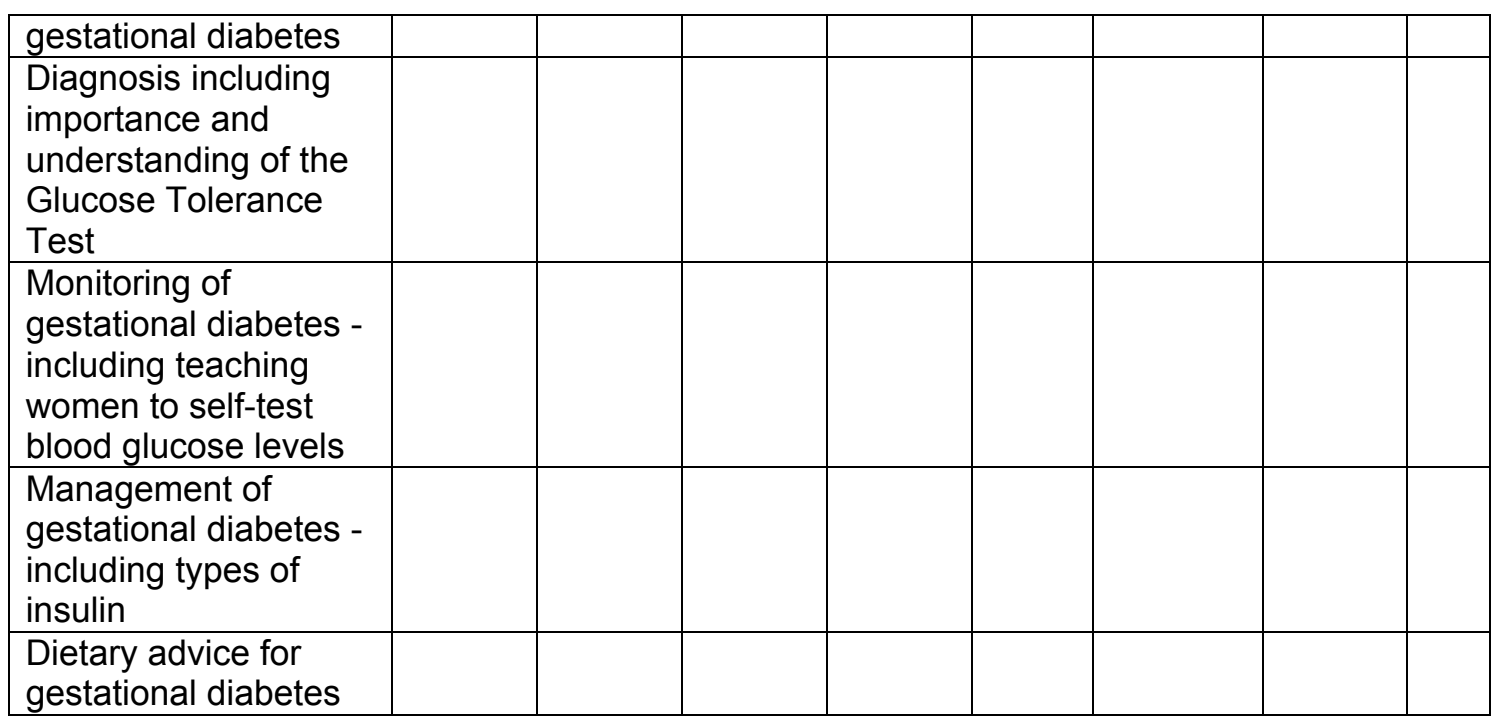

Other (please specify)

18. Would you like formal (accredited) training in any of the following areas of gestational diabetes management:

\begin{tabular}{|l|l|l|}
\hline & Yes & No \\
\hline Causes and physiology of gestational diabetes & & \\
\hline Gestational diabetes prevention & & \\
\hline Screening for gestational diabetes & & \\
\hline Diagnosis including importance and understanding of the & & \\
Glucose Tolerance Test & & \\
\hline $\begin{array}{l}\text { Monitoring of gestational diabetes - including teaching women to } \\
\text { self-test blood glucose levels }\end{array}$ & & \\
\hline Management of gestational diabetes - including types of insulin & & \\
\hline Dietary advice for gestational diabetes & & \\
\hline
\end{tabular}

If you answered no to any of the above, please specify why not

Please tell us about your expertise and training needs

19. How would you rate your expertise/knowledge in the following areas?

\begin{tabular}{|l|l|l|l|l|l|}
\hline & Excellent & $\begin{array}{l}\text { Very } \\
\text { Good }\end{array}$ & Good & Fair & Poor \\
\hline $\begin{array}{l}\text { Providing pre-conception advice for } \\
\text { women with diabetes }\end{array}$ & & & & & \\
\hline $\begin{array}{l}\text { Awareness of the psychological } \\
\text { effect that diabetes can have on } \\
\text { pregnant women }\end{array}$ & & & & & \\
\hline $\begin{array}{l}\text { Risks and complications of } \\
\text { diabetes during pregnancy, labour }\end{array}$ & & & & & \\
\hline
\end{tabular}


Appendix 3 Full text of Midwife Survey continued

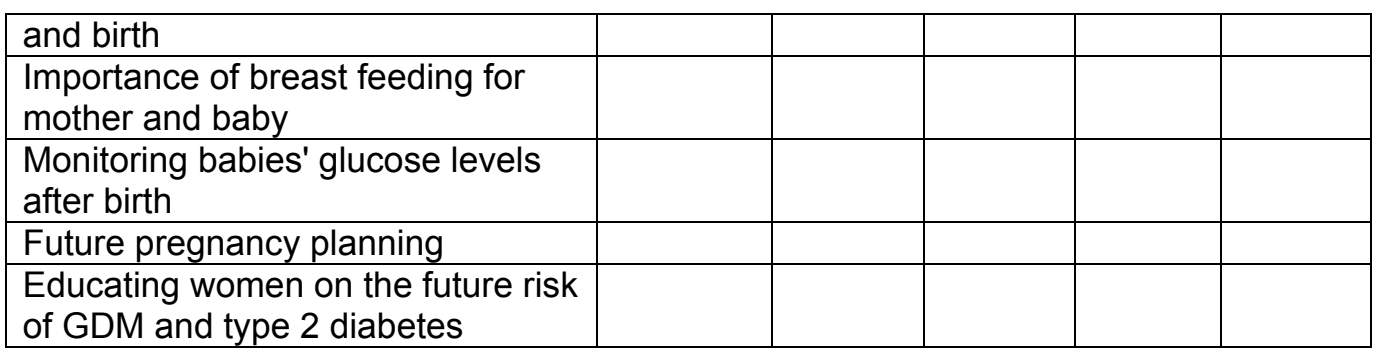

20. Have you had any training, as a midwife, in the following areas of gestational diabetes management? (Please tick all boxes that are relevant)

\begin{tabular}{|c|c|c|c|c|c|c|c|c|}
\hline & $\begin{array}{l}\text { Yes, on } \\
\text { the ward } \\
\text { or in clinic } \\
\text { from my } \\
\text { colleagues }\end{array}$ & $\begin{array}{l}\text { Yes, via } \\
\text { in-house } \\
\text { statutory } \\
\text { training }\end{array}$ & $\begin{array}{l}\text { Yes, via } \\
\text { self- } \\
\text { directed } \\
\text { learning }\end{array}$ & $\begin{array}{l}\text { Yes, via } \\
\text { an e- } \\
\text { learning } \\
\text { module }\end{array}$ & $\begin{array}{l}\text { Yes, } \\
\text { on a } \\
\text { study } \\
\text { day or } \\
\text { short } \\
\text { course }\end{array}$ & $\begin{array}{l}\text { Yes, on a } \\
\text { university } \\
\text { accredited } \\
\text { course }\end{array}$ & $\begin{array}{l}\text { Yes, as } \\
\text { part of } \\
\text { my } \\
\text { student } \\
\text { midwifery } \\
\text { training }\end{array}$ & No \\
\hline $\begin{array}{l}\text { Providing } \\
\text { pre- } \\
\text { conception } \\
\text { advice for } \\
\text { women with } \\
\text { diabetes }\end{array}$ & & & & & & & & \\
\hline $\begin{array}{l}\text { Awareness of } \\
\text { the } \\
\text { psychological } \\
\text { effect that } \\
\text { diabetes can } \\
\text { have on } \\
\text { pregnant } \\
\text { women }\end{array}$ & & & & & & & & \\
\hline $\begin{array}{l}\text { Risks and } \\
\text { complications } \\
\text { of diabetes } \\
\text { during } \\
\text { pregnancy, } \\
\text { labour and } \\
\text { birth }\end{array}$ & & & & & & & & \\
\hline $\begin{array}{l}\text { Importance } \\
\text { of breast } \\
\text { feeding for } \\
\text { mother and } \\
\text { baby }\end{array}$ & & & & & & & & \\
\hline $\begin{array}{l}\text { Monitoring } \\
\text { babies' } \\
\text { glucose } \\
\text { levels after } \\
\text { birth }\end{array}$ & & & & & & & & \\
\hline
\end{tabular}

Continued.. 
Appendix 3 Full text of Midwife Survey continued

\begin{tabular}{|l|l|l|l|l|l|l|l|}
\hline $\begin{array}{l}\text { Future } \\
\text { pregnancy } \\
\text { planning }\end{array}$ & & & & & & & \\
\hline Educating & & & & & & & \\
women on \\
the future risk \\
of GDM and \\
type 2
\end{tabular}

Other (please specify)

21. Would you like formal (accredited) training in any of the following areas of gestational diabetes management?

\begin{tabular}{|l|l|l|}
\hline & Yes & No \\
\hline Providing pre-conception advice for women with diabetes & & \\
\hline $\begin{array}{l}\text { Awareness of the psychological effect that diabetes can have on } \\
\text { pregnant women }\end{array}$ & & \\
\hline $\begin{array}{l}\text { Risks and complications of diabetes during pregnancy, labour and } \\
\text { birth }\end{array}$ & & \\
\hline Importance of breast feeding for mother and baby & & \\
\hline Monitoring babies' glucose levels after birth & & \\
\hline Future pregnancy planning & & \\
\hline Educating women on the future risk of GDM and type 2 diabetes & & \\
\hline
\end{tabular}

If you answered no to any of the above, please specify why not

Please tell us about the support you receive from your local Diabetes Specialist

Team

22. How easy is it to obtain advice from the Diabetes Specialist Team

(Consultant Obstetrician, Consultant Endocrinologist/ Diabetologist, Specialist

Diabetes Nurse, Specialist Diabetes Midwife, Specialist Diabetes Dietician)?

Very easy

Easy

Neither easy nor difficult

Difficult

Very difficult

Please provide further details

23. Do you receive training from members of your local Diabetes Specialist

Team?

No

Yes - less than once a year

Yes - annually (once a year)

Yes - biannually (twice a year)

Yes - more than twice a year

Yes - on an ongoing basis 
Yes - on an ad hoc basis

Other (please specify)

24. If you do receive training from your Diabetes Specialist Team, how long is this training usually?

Up to 30 minutes

Up to one hour

Between one and two hours

Half a day

One day

N/A

25. If you do receive training from the Diabetes Specialist Team, can you use study leave to attend?

Yes

No

$\mathrm{N} / \mathrm{A}$

Please comment

26. Does your Trust have a Multi-Disciplinary Team Meeting (MDM/ MDT) or planning meeting where difficult pregnancy cases including those with diabetes are discussed involving the wider healthcare team (including, for example, paediatrics, anaesthetics)?

Yes

No

Don't know

If yes, who attends from the midwifery team?

27. Who would you go to for advice about a pregnant woman with diabetes? (Please tick all that apply)

Diabetes Specialist Midwife (or similar)

Midwife colleague

Consultant Obstetrician

Consultant Diabetologist/Endocrinologist

Diabetes Specialist Nurse

Diabetes Specialist Dietician

Other (please specify)

Please tell us about any benefits of midwives taking an active role in diabetes management

28. Are there advantages for pregnant women if midwives are more knowledgable about diabetes management in pregnancy?

No

Yes, please specify 
29. In your opinion, what is the importance to pregnant women of having a Diabetes Specialist Midwife or similar taking an active role in diabetes management?

\begin{tabular}{|l|l|l|l|l|l|}
\hline & $\begin{array}{l}\text { Very } \\
\text { importa } \\
\text { nt }\end{array}$ & $\begin{array}{l}\text { Quite } \\
\text { importa } \\
\text { nt }\end{array}$ & $\begin{array}{l}\text { Neither } \\
\text { importa } \\
\text { nt nor } \\
\text { unimpo } \\
\text { rtant }\end{array}$ & $\begin{array}{l}\text { Not } \\
\text { very } \\
\text { importa } \\
\text { nt }\end{array}$ & $\begin{array}{l}\text { Unimpo } \\
\text { rtant }\end{array}$ \\
\hline $\begin{array}{l}\text { Improved continuity of care } \\
\text { inpatient stay before birth }\end{array}$ & & & & & \\
\hline $\begin{array}{l}\text { Reduced stress for pregnant } \\
\text { women }\end{array}$ & & & & & \\
\hline $\begin{array}{l}\text { Easy access to information and } \\
\text { support to midwife with } \\
\text { specialist knowledge of both } \\
\text { diabetes and pregnancy }\end{array}$ & & & & & \\
\hline $\begin{array}{l}\text { Improved outcomes for babies } \\
\text { including fewer macrosomic } \\
\text { babies }\end{array}$ & & & & & \\
\hline $\begin{array}{l}\text { Improved outcomes for } \\
\text { pregnant women including fewer } \\
\text { complications }\end{array}$ & & & & & \\
\hline Improved patient experience & & & & & \\
\hline Improved consistency of care & & & & & \\
\hline
\end{tabular}

30. In your opinion, what is the importance to midwives of having a Diabetes Specialist Midwife or similar taking an active role in diabetes management?

\begin{tabular}{|l|l|l|l|l|l|}
\hline & $\begin{array}{l}\text { Very } \\
\text { importa } \\
\text { nt }\end{array}$ & $\begin{array}{l}\text { Quite } \\
\text { importa } \\
\text { nt }\end{array}$ & $\begin{array}{l}\text { Neither } \\
\text { importa } \\
\text { nt nor } \\
\text { unimpor } \\
\text { tant }\end{array}$ & $\begin{array}{l}\text { Not } \\
\text { very } \\
\text { importa } \\
\text { nt }\end{array}$ & $\begin{array}{l}\text { Unimpo } \\
\text { rtant }\end{array}$ \\
\hline $\begin{array}{l}\text { Improved control of diabetes } \\
\text { during pregnancy and birth }\end{array}$ & & & & & \\
\hline $\begin{array}{l}\text { Personalised care for each } \\
\text { woman }\end{array}$ & & & & & \\
\hline $\begin{array}{l}\text { Empowering women to control } \\
\text { their glucose levels }\end{array}$ & & & & & \\
\hline $\begin{array}{l}\text { Confidence and knowledge to } \\
\text { reassure women }\end{array}$ & & & & & \\
\hline $\begin{array}{l}\text { Spread knowledge of diabetes } \\
\text { management in pregnancy } \\
\text { across the midwifery team }\end{array}$ & & & & & \\
\hline $\begin{array}{l}\text { Improved achievement of own } \\
\text { education goals }\end{array}$ & & & & & \\
\hline
\end{tabular}




\begin{tabular}{|l|l|l|l|l|l|}
\hline Improved job satisfaction & & & & & \\
\hline Improved links to the Diabetes & & & & & \\
Specialist Team & & & & & \\
\hline
\end{tabular}

31. In your opinion, what is the importance to NHS Trusts of having a Diabetes Specialist Midwife or similar taking an active role in diabetes management?

\begin{tabular}{|l|l|l|l|l|l|}
\hline & $\begin{array}{l}\text { Very } \\
\text { importa } \\
\text { nt }\end{array}$ & $\begin{array}{l}\text { Quite } \\
\text { importa } \\
\text { nt }\end{array}$ & $\begin{array}{l}\text { Neither } \\
\text { liportant } \\
\text { nor } \\
\text { unimpor } \\
\text { tant }\end{array}$ & $\begin{array}{l}\text { Not } \\
\text { very } \\
\text { importa } \\
\text { nt }\end{array}$ & $\begin{array}{l}\text { Unimpo } \\
\text { rtant }\end{array}$ \\
\hline $\begin{array}{l}\text { Reduced number of hospital } \\
\text { admissions }\end{array}$ & & & & & \\
\hline $\begin{array}{l}\text { Reduced hospital length of } \\
\text { stays }\end{array}$ & & & & & \\
\hline $\begin{array}{l}\text { Providing a high standard of } \\
\text { care }\end{array}$ & & & & & \\
\hline $\begin{array}{l}\text { Reduced cost for providing } \\
\text { diabetes care }\end{array}$ & & & & & \\
\hline $\begin{array}{l}\text { Financial benefits from } \\
\text { reducing complaints and } \\
\text { litigation costs }\end{array}$ & & & & & \\
\hline $\begin{array}{l}\text { Reduced demand on high cost } \\
\text { care for mother and/or baby }\end{array}$ & & & & & \\
\hline Improved workforce loyalty & & & & & \\
\hline
\end{tabular}

32. Do you have any other comments you would like to share about managing pregnant women with diabetes and receiving training in this aspect of care? (Please do NOT mention any names)

No

Yes (please specify)

Please tell us about where you work

33. Where do you work?

England - North of England

England - Midlands and East of England

England - London

England - South of England

Wales

Northern Ireland

Scotland

Contact details and prize draw! Please scroll down to the bottom of the page to complete the Survey

34. If you are interested in being contacted for further research or to support the development of a training course, please provide your contact details 
below. The survey is anonymous and any contact information we collect from you will be kept separately from your responses. If you agree to be contacted for a follow-up, you can always decline the request when contacted.

Name

Email address

Telephone number (optional)

35. If you would like to take part in the prize draw to win a $£ 100$ Amazon gift voucher, please provide your contact details below. Any contact information we collect from you to participate for the draw will be stored separately from your answers to the survey questions, and will be deleted once the draw is complete.

Name

Email address 